\title{
Kernos
}

Revue internationale et pluridisciplinaire de religion grecque antique

$26 \mid 2013$

Varia

\section{Modes of Prophecy, or Modern Arguments in Support of the Ancient Approach}

\section{Yulia Ustinova}

\section{Q OpenEdition \\ Journals}

Electronic version

URL: http://journals.openedition.org/kernos/2197

DOI: 10.4000/kernos.2197

ISSN: 2034-7871

\section{Publisher}

Centre international d'étude de la religion grecque antique

\section{Printed version}

Date of publication: 10 October 2013

Number of pages: $25-44$

ISSN: 0776-3824

\section{Electronic reference}

Yulia Ustinova, "Modes of Prophecy, or Modern Arguments in Support of the Ancient Approach", Kernos [Online], 26 | 2013, Online since 31 October 2015, connection on 02 March 2021. URL: http:// journals.openedition.org/kernos/2197 ; DOI: https://doi.org/10.4000/kernos.2197 


\title{
Modes of Prophecy, or Modern Arguments in Support of the Ancient Approach ${ }^{1}$
}

\begin{abstract}
Inspired prophecy and divination by signs involve different activities and require different abilities on the part of their practitioners. A re-examination of ancient sources demonstrates that the idea of the supremacy of direct prophecy cannot be dismissed as a Platonic invention. Moreover, modes of prophecy are far from being a modern construal: they were already perceived as such in the second millennium BC. Ecstatic prophecy, difficult to achieve and dependent on the will of the gods, was open-ended and difficult to manipulate. Hence, most experts regard direct divination in Mesopotamia as peripheral to traditional divination by signs: it is the reverse correlation in Greece that requires an explanation. To discard the dichotomy between direct and indirect prophecy is to strip Greek culture of one of its unique characteristics.

Résumé : La prophétie inspirée et la divination par les signes impliquent des activités distinctes et requièrent des compétences différentes de ceux qui les pratiquent. Une relecture des sources anciennes débouche sur l'idée que la suprématie de la prophétie directe ne peut être écartée comme une invention platonicienne. Des modes de prophétie sont loin d'être une interprétation moderne et ils étaient déjà perçus ainsi au second millénaire avant notre ère. La prophétie extatique, phénomène précieux, dépendant de la volonté des dieux, était imprévisible et difficile à manipuler. Il n'est pas étonnant que la plupart des spécialistes définissent la divination directe en Mésopotamie comme secondaire par comparaison avec la divination traditionnelle par les signes; c'est la situation en Grèce, où la corrélation est inverse, ce qui demande une explication. Abandonner la dichotomie entre prophétie directe et indirecte revient à retirer à la culture grecque une de ses caractéristiques principales.
\end{abstract}

Until recently, the ancient division between direct and indirect divination, introduced into modern research of the Classical world by A. BouchéLeclercq, ${ }^{2}$ seemed self-evident and was accepted unanimously. Lately, however, the scholarly consensus has been somewhat undermined. In particular, several participants in the 13th CIERGA colloquium, in their papers and during discussions, demonstrated the growing skepticism on this dichotomy: they question not only its usefulness, but even its origins in ancient evidence rather than in modern (mis)construing. The corollaries of this dispute are very

${ }^{1}$ I am grateful to Lucien Poznanski for his support in the preparation of this paper, to Chaya Galay who improved its English style, and to the anonymous reviewer of this paper for his comments. Many thanks to the colleagues who attended my lecture on modes of prophecy at the Institute of Classical Studies, UCL, for their helpful comments.

2 BOUCHÉ-LECLERCQ (1879-1882), vol. 1, p. 107-110. 
important. As E.M. Zeusse observes, "the depending in particular cultures... or subgroups of a culture on 'objective' augury methods, or on methods that progressively encroach or even obliterate ego awareness, suggest differing views of the self, society, and the world."'3 Accurate assessment of the attitude of the Greeks to various methods of divination is therefore essential for the understanding of the Hellenic culture, and must be based on a typology summarizing ancient practices as faithfully as possible. The aim of this paper is to call attention to the importance of the ancient typology and to support it with additional arguments, based on re-examination of Greek evidence and comparative research on prophecy in the ancient Mediterranean. ${ }^{4}$

\section{Basic ancient evidence}

Any discussion of modes of prophecy in Greece should commence with a set of well-known quotations from Plato and Cicero. In the Timaeus, the distinction between $\mu \alpha \dot{\alpha} \tau \varepsilon \iota \varsigma$ and $\pi \varrho O \varphi \tilde{\eta} \tau \alpha \iota$ is pronounced and explained in detail:

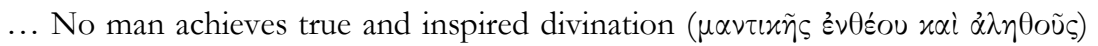
when in his rational mind ('́vvous), but only when the power of his intelligence is fettered in sleep or when it is distraught by disease or by reason of some divine

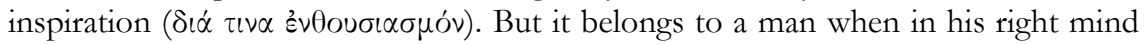

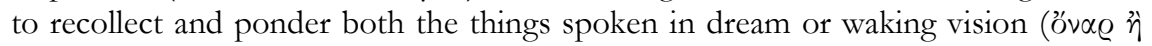
$\because \pi \alpha \varrho) \ldots$ But it is not the task of him who has been in a state of frenzy ( $\tau 0 \tilde{u}$ $\mu \alpha \nu \varepsilon ́ v \tau O \varsigma)$, and still continues therein, to judge the apparitions and voices seen or uttered by himself; for it was well said of old that to do so and to know one's own and oneself belongs only to him who is sound of mind. Wherefore also it is customary to set the tribe of prophets $(\pi \varrho \circ \varphi \eta \tau \tilde{\omega} \nu)$ to pass judgment upon these in-

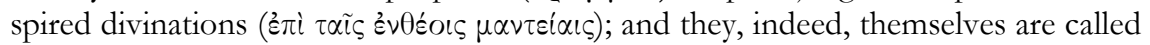
"diviners" ( $\mu \alpha \dot{\alpha} \tau \varepsilon \iota \varsigma)$ by certain who are wholly ignorant of the truth that they are not diviners but interpreters of the mysterious voice and apparition, for whom the most fitting name would be "prophets of things divined" (

This passage asserts that true $\mu \alpha \nu \tau \iota x \dot{\eta}$ is possible only in an altered state of consciousness, and never in the regular waking condition. ${ }^{6}$ The exact nature of alteration of consciousness, whether dream or vision, induced by illness or divine inspiration, is irrelevant to Plato. In any case, the message may be interpreted only by a sober man, either the experiencer himself, after he has

\footnotetext{
3 ZEUSSE (1987), p. 377.

${ }^{4}$ For methodological problems of the comparative perspective see BARSTAD (2000); GRABBE (2000), p. 14-16; Overholt (1986), p. 4-7; (1989), p. 5-15; Wilson (1980), p. 14-16. Although prophecy is a cross-cultural phenomenon, in Classical studies this direction of research remains rare: Whittaker (1965); Aune (1983); PARKer (1985); PARKe (1988); MAurizio (1995); PiÑero (1991); BREMMER (1993).

5 Tim., 71e-72b (translation R.G. Bury); cf. NAGY (1990), p. 60-61; MANETTI (1990), p. 16.

${ }^{6}$ On alteration of consciousness and the Greek culture, see UsTiNOVA (2009); (2011).
} 
emerged from this abnormal state, or another person. Finally, Plato's contemporaries did not always observe the terminological precision required by the philosopher, and confused $\mu \alpha \dot{\alpha} \tau \varepsilon \iota \varsigma$ and $\pi \varrho \circ \varphi \tilde{\eta} \tau \alpha \iota$ in their speech. ${ }^{7}$

Plato refers to the difference between inspired and technical divination in other dialogues, as well. In the famous passage in the Phaedrus, Socrates says that the greatest blessings come to mortals through madness, when it is a gift of

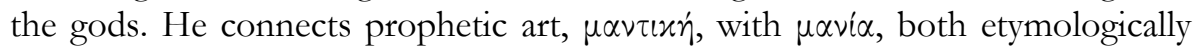
and in essence, ${ }^{8}$ and continues:

... When they gave a name to the investigation of future which rational persons (oi é $\mu \varphi \varrho O v \varepsilon \varsigma$ ) conduct through observation of birds and by other signs, since they furnish mind and information to human thought (o'noıs), from the intellect, they call it oinoistic (oiovoเ $\left.\tau \iota x \eta^{\prime}\right)$ art... The ancients then testify that in proportion as

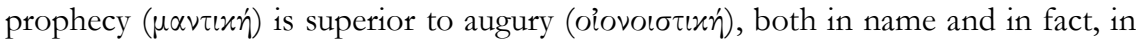
the same proportion madness ( $\left.\mu \alpha v^{\prime} \alpha\right)$, which comes from god, is superior to sanity, which is of human origin. ${ }^{?}$

The later Greek tradition is reconstructed mostly on the basis of Cicero's De divinatione, referring to Dicaearchus and Cratippus as his authorities on divination. ${ }^{10}$ Following the Greeks, Cicero states that

... You divided divination into two modes, artificial (artificiousum) and natural (naturale). Artificial divination... is based partially on conjecture, and partially on prolonged observation. Natural divination comes from the spirit seizing and obtaining information from an external source, from the god... You will refer to the artificial divination almost all the existing techniques: extispicy, prediction of the future by the lightening and other prodigies, augury and the use of signs and omens. Natural divination, on the contrary, ... is incited or induced by the exaltation of the spirit (concitatione mentis), or produced in sleep by the soul liberated from sensations and troubles. ${ }^{11}$

Thus, Plato and Cicero perceived two kinds of divination, one based on observation of signs and the other, ensuing from divine inspiration, which could be obtained only in a state other than regular waking consciousness, that is, while in the grip of a deity, in an attack of frenzy, or in sleep.

${ }^{7}$ Georgoudi (1998), p. 328-334; Dillery (2005), p. 171.

8 The etymological connection is clear to modern scholars, as well: FRISK (1973-1979), s.v. mainomai; CHANTRAINE (1983-1984), s.v. mainomai. Both words derive from the Indo-European root *men meaning 'to be in a special, or differentiated, state of consciousness,' WeST (2007), p. 29; NAgy (1990), p. 60; Manetti (1993), p. 14; Dillery (2005), p. 169; Ustinova (2009), p. 10. For a different opinion see CASEVITZ (1992).

9 244a-b (translation by W.R.M. Lamb); HACKFORTH (1972) p. 60; ROwE (1986), p. 168-173.

${ }^{10} \mathrm{II}, 48-49$.

${ }^{11}$ De div. II, 11, cf. I, 6; I, 18. 


\section{The traditional modern approach}

Since A. Bouché-Leclercq, most Classical scholars have maintained that in the Greco-Roman world, there were two ways to ascertain the will of the gods: either directly, by means of pronouncements by a person believed to serve as a transmitter of the divine truth or will, or indirectly, by interpretation of signs or omens. Transmission was a natural or divine gift, hence $\mu \alpha \nu \tau \iota x \dot{\eta} \ddot{\alpha} \tau \varepsilon \chi \nu \circ \varsigma$ for the Greeks and divinatio naturalis for the Romans, whereas interpretation could be learnt as an art, therefore respectively $\mu \alpha \nu \tau \iota \dot{\eta}$ है $\nu \tau \varepsilon \chi \nu O \varsigma$ and divinatio artificiosa. ${ }^{12}$ Terms used by modern Classical scholars differ: direct, intuitive, inspired, or enthused on the one hand, indirect, inductive or deductive on the other. Most studies of Greek divination still adhere to the ancient division. ${ }^{13}$

Indirect divination comprised numerous methods. In addition to extispicy, which was the most common technique, there were ornithomancy, cleromancy, pyromancy, lecanomancy, etc. These were crafts to be learnt: "many ways of

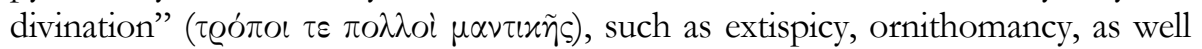
as interpretation of dreams and unspecified sound omens and signs ( $x \lambda \eta \delta$ óv $\alpha \varsigma .$.

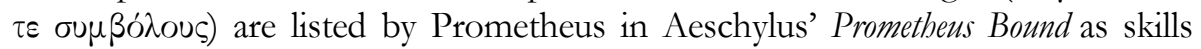
that he taught to humankind. ${ }^{14}$ Interpretation of written oracles assembled in books ascribed to Orpheus, Musaeus, and Bakis, ${ }^{15}$ and distributed by itinerant and sedentary oracle-mongers, could be a prosperous business. ${ }^{16}$ Although sometimes adverse omens could be very troublesome, ${ }^{17}$ on the whole these methods, regarded as routine procedures, seem to have been managed smoothly.

In contrast, inspired prophecy was always associated with special conditions. To gain inspiration, a mortal had to become possessed by a god ( $\theta \varepsilon o ́ \lambda \eta \pi \tau o \varsigma$ or $x \alpha \dot{\alpha} \tau \chi 0 \varsigma)$, or to have the god inside him ( $\varepsilon \dot{v} \theta \varepsilon \circ \varsigma)$ : the seer $(\mu \alpha \dot{\alpha} \nu \iota \varsigma)$ or prophet

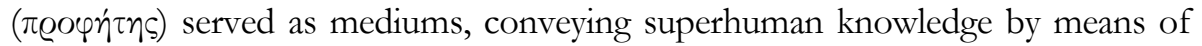
their bodies. ${ }^{18}$ When in the grip of the god, the medium could display a wide range of abnormal behavior, from mere detachment to violent paroxysms. These mental states, which today would be referred to as 'altered states of conscious-

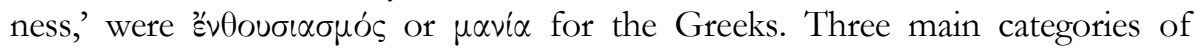
individuals could be endowed with divinely inspired revelation: religious personnel of established oracular shrines, independent seers, and inquirers in

12 Bouché-Leclerce (1879-1882), vol. 1, p. 62; NilsSON (1961-1967), vol. 1, p. 164; BELAYCHE - RÜPKE (2005), p. 80.

13 BouChÉ-LeClerCQ (1879-1882), vol. 1, p. 107-110; FlaCelière (1972); DodDS (1973), p. 70; MANeTti (1990), p. 19; KarP (1998), p. 13; Dietrich (1990); Rosenberger (2001); BURKERT (2005a); (2005b); BELAYCHE - RÜPKE (2005), p. 80; JOHNSTON (2008), p. 8-9.

${ }^{14}$ Lines 484-499; cf. Flower (2008), p. 90-91; JOHNSTON (2008), p. 125-141.

15 Dillery (2005), p. 179-180; PARKe (1988), p. 180.

${ }^{16}$ E.g. Isocrates, 19; Plato, Rep., 364B-365A; for itinerant seers see BuRKERT (1983).

${ }^{17}$ E.g. Hdt., IX, 61; Xen., An. IV, 4, 22; Powell (2009).

18 On cult officials in oracular shrines, see GEORGOUDI (1998). 
oracular centers based on direct communication between the consulter and the deity.

\section{Challenges to the traditional approach: facts and interpre- tations}

Some mythological seers were equally skilled at indirect and direct prophecy. For instance, Malampous, the inventor of divination and an expert in extispicy, understood the language of animals, purified, cured, and founded a dynasty of seers. ${ }^{19}$ His descendants, Theoclymenus and Amphiaraus, interpreted signs and predicted the future by divine inspiration. ${ }^{20}$ Helenus, "the best of the ornithomancers," was also able to hear the voice of the gods. ${ }^{21}$

A conjunction of inspired and technical modes of divination was not unusual. The most famous example is Delphi, where cleromancy co-existed with inspired prophecy. ${ }^{22}$ The great Corycian cave served as a seat of a lot oracle, but cases of nympholepsy occurred there, as well. ${ }^{23}$ Different modes of prophecy co-existed in Dodona. ${ }^{24}$ Collaboration between an ecstatic mouthpiece of the gods and sober officials recording the divine messages is attested to as existing in several oracular centers, for instance at Delphi and Claros. ${ }^{25}$ The lack of terminological consistency condemned by Plato, and the ongoing scholarly dispute on the functions of ecstatic and non-ecstatic personnel in several sanctuaries, ${ }^{26}$ indicate that the time-honored dichotomy needs to be qualified.

M.A. Flower refutes the traditional approach, arguing that, firstly, various methods of divination were sometimes combined; secondly, social function of prediction by all the methods was the same, and thirdly, ecstatic prophecy needed to be interpreted rationally. His own suggestion is somewhat amorphous: either to regard any distinction between different types of divination as misleading, and

${ }^{19}$ Her., II, 49; IX, 34; Apollod., II, 2, 2; Paus., V, 5, 10; BouChÉ-LeCLERCQ (1879-1882), vol. 2, p. 16-18.

${ }^{20}$ Paus., V, 13, 6; Apollod., III, 6, 4; Aeschyl., Sept., 276; Od. XX, 351-355; Dillery (2005), p. $173-176$.

${ }^{21}$ Il. VI, 76; VII, 53.

22 Parke - Wormell (1956), vol. 1, p. 18; Rosenberger (2001), p. 56; LARSON (2001), p. 235.

${ }^{23}$ UstinOVA (2009), p. 65-68.

${ }^{24}$ GARTZIOU-TATTI (1990); GEORGOUdi (2012). S. JOHNSTON (2008), p. 72, suggests that in Dodona signs of different nature, such as the words of dove priestesses, as well as sounds produced by doves, cauldrons, and oak trees, were 'interpreted by women, while in an altered state of consciousness, to be messages from Zeus'. However, ecstatic interpretation of signs implies a contradiction in terms - interpretation is bound to be rational, - and since no detail of this procedure is known, S. Johnston's 'single model' remains unsubstantiated.

25 Ustinova (2011), p. 111, 124.

${ }^{26}$ Georgoudi (1998), p. 348-355; Dillery (2005), p. 169-172; Ustinova (2011), p. 111. 
"rather think in terms of spectrum or range of activities," 27 or to assume a threefold classification, comprising possession divination, technical divination, and intuitive divination. L. Maurizio adopts a typology based on Chinese materials: divination is divided into non-interpersonal (lacking interaction between the diviner and the spirits, e.g. horoscopy) and interpersonal (including spirit possession along with augury, and regarding devices, such as stones and birds, as possessed by spirits). ${ }^{28}$

Scholars, who convened in Paris in 2005 to discuss attitudes to signs and omens in the ancient Mediterranean, either disregarded the contrast between divination by signs and direct prophecy, or explicitly argued that the two were interdependent practices, rather than conflicting categories. ${ }^{29}$ In his book on oracles, R. Stoneman devotes a chapter to definitions of various oracular practices, but does not distinguish clearly between inspired and technical divination. In emphasizing the spoken word of the oracles, he does not discriminate between the utterances of inspired mediums and the pronouncements of interpreters. ${ }^{30} \mathrm{At}$ a recent conference in Chicago, ${ }^{31}$ several scholars suggested that the contrast between direct and indirect divination was more superficial than previously thought. To be sure, in antiquity both omens and prophetic utterings were considered indications of the divine will, and the Stoics developed this notion coherently. ${ }^{32}$ For a modern researcher, the two modes are "two sides of the same coin," triggered by the human urge to overcome insecurity by ascertaining the divine will. ${ }^{33}$ From these incontestable observations, A. Winitzer proceeds further, asserting that signs obtained by extispicy or other modes of divination were envisaged by Mesopotamians as "divinely inspired in some transcendental fashion," and deducing that "divination... is nothing less than a source of revelation, its product tantamount to the divinely related word." 34 These models and typologies call for a reassessment of some basic issues in the study of ancient Mediterranean divination.

\footnotetext{
${ }^{27}$ FLOWER (2008), p. 84-91.

28 Maurizio (1995), p. 79-80.

${ }^{29}$ GeOrgoudi - Koch-PietTRE - SCHMidt (2012).

${ }^{30}$ STONEMAN (2011), esp. p. 19.

31 ANNus (2010).

32 AlLEN (2010), p. 36.

${ }^{33}$ NisSinen (2010).

34 WinitZER (2010), p. 181.
} 


\section{Arguments in support of the traditional approach: addi- tional Greek evidence}

\subsection{The inspired prophet as an instrument of the gods}

A great gap separated diviners, whose aptitude was unlimited in time, from inspired seers, whose prophecy was directly initiated and sustained by the will of the gods at the very moment when the immortals used a human being as a mouthpiece. Plato related to this issue in the Meno, stating that soothsayers and

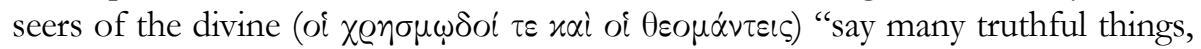
but don't realize anything they say." 35 Several centuries later, Plutarch compared the soul of the Pythia to a musical instrument, which produces music as the result of interaction between its own nature and an exterior force, and emphasized the interaction between the Pythia's soul and the external (divine) force in the process of prophecy-giving. ${ }^{36}$ Iamblichus takes this idea even further, and groups together all the intermediate instruments sent forth by the gods to mortals in order to guide them, inanimate objects as well as human seers:

For if this divine power extends in its predictions to inanimate objects, such as little pebbles, rods, or certain woods ... it gives life to inanimate things and motion to things motionless, and makes all clear, knowledgeable, and participating in reason... and yet having no reason in themselves... And just as he makes some simple-minded human being ( $\tau \tilde{\omega} \nu \operatorname{\varepsilon } \dot{\eta} \eta \omega \omega \tilde{\omega} \nu \tau \tau \nu \alpha \dot{\alpha} v \theta \varrho \dot{\omega} \pi \omega \nu)$ utter statements full of wisdom, by which it becomes clear to all that this is not some human but a divine accomplishment, so through beings deprived of knowledge he reveals thoughts which surpass all knowledge. At the same time, the god manifests to humans that the signs shown are worth of credence, and that they are superior to nature, and god is exalted above it. ${ }^{37}$

Plutarch's idea that the Pythia's soul possessed the inborn ability to prophesy probably reflects the Platonic conception, which was also adopted by the Stoics, ${ }^{38}$ of souls acquiring this ability in certain states, such as sleep or imminent death; Iamblichus' thought combined Neoplatonism with theurgy; ${ }^{39}$ both Iamblichus and Plutarch may have been influenced by Plato's statements in the Meno and elsewhere. All that does not change the fact that for these thinkers, an inspired seer was an instrument used by the gods, more akin to a

\footnotetext{
35 99c-d. Here again, one would have preferred Plato to respect his own rules of word usage, rather than carelessly adopt the popular parlance. Cf. Ion, 534c-d; 22b-c and Euthyphro passim; MikALSON (2010), p. 126-129.

36 Mor., 404f; 414e; 431b, cf. JoHnSTON (2008), p. 10; JAILLARD (2007).

${ }^{37}$ De myst. III, 17 (translation E.C. Clarke, J.M. Dillon, J.P. Hershbell).

38 Plut., Mor., 432c-d; Plato, Tim., 71e, cf. Cic., De div. I. 30; Amandry (1950), p. 222-224; SCHRÖDER (1990), p. 24-59.

39 SHAW (1998).
} 
bird directed by the divine will than to an interpreter of its flight. Inspired prophecy emanated from the gods directly, the seer being a divine instrument, while interpretation of signs involved human explanation of actions of divine instruments (such as birds, prodigies, etc.). This introduced an additional stage, an agent separating the divine from the human.

Homer is the earliest source for evidence that direct contacts with the gods were evaluated as superior to interpretation of signs. For instance, Priam assures Hecabe that if they were advised to ransom Hector's body by mortals,

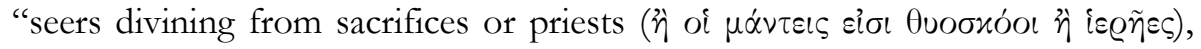
we would consider it false and turn away from it still more; but now that I heard the goddess myself and I looked at her, I will go, and her word will not be wasted." ${ }^{40}$ Unmediated contact with a god, in a dream or when awake, is quite common in the Homeric epos; ${ }^{41}$ in later ages and in the lives of less heroic humans it was replaced by the closest equivalents, direct prophecy and incubation. Thus, the idea of the supremacy of direct communication from the gods, appearing as early as in Homer, cannot be dismissed as an ideologically prompted Platonic invention. ${ }^{42}$ Furthermore, Priam's words affirm that the difference between direct and indirect prophecy was extremely important from the inquirer's point of view - contrary to M.A. Flower's opinion that the client could be indifferent to the method of divination. ${ }^{43}$

\subsection{Costs of direct prophecy}

To attain superhuman knowledge was the greatest challenge, and the path to such knowledge was perilous and excruciating. At Claros, the act of drinking from the sacred pool inspired oracles, but shortened the life of the drinker. ${ }^{44}$ Compelled to predict against her will, the Pythia risked illness and death. ${ }^{45}$ The agony of prophecy is described more than once in Classical literature. Heraclitus

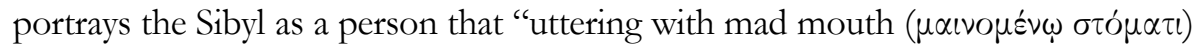
cheerless, unembellished, unperfumed words, reaches to a thousand years with

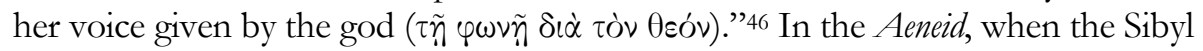
utters her prophecy, her face changes color, her breast heaves, her voice's timbre

\footnotetext{
${ }^{40}$ Il. XXIV, 221-224.

${ }^{41}$ E.g. Il. I, 193-218; III, 396-418; XIV, 361-378.

42 As Flower (2008), p. 85.

${ }^{43}$ FLOWER (2008), p. 87.

44 Plin., Hist. Nat. II, 232; Iamb., De myst. III, 11; Ustinova (2009), p. 111.

45 Plut., Mor., 438a-b, cf. Lucan, V, 147-196; Ustinova (2009), p. 139-142. In a Norse saga, a wise woman, when posed two questions by the same person, says: "I will not undergo this great strain again, for it has been of no small cost to me, and neither threads nor fair words will be of any avail," DAVIDSON (1981), p. 135. Nowadays, at the Nechung oracle in Tibet, the prophetic trance consumes all the energies of the medium known as the Kuden, ARNOTT (1989).

${ }^{46}$ Heracl., fr. 92 (Diels-KRANZ) = Mor., 397a; PARKe (1988), p. 63.
} 
is altered, and "her heart swells with wild frenzy."47 Virgil's and Heraclitus' portraits of the Sibyl are almost identical to Aeschylus' description of Cassandra,

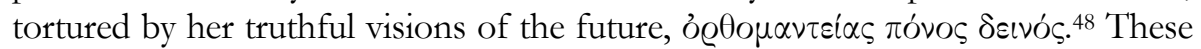
scenes can hardly be taken for candid descriptions of actual oracular practices, but they convey their authors' ideas on ecstatic prophecy-giving. The prophetic experiences of one-time inquirers at the Trophonium were so awesome that it was said that they lost the ability to smile. ${ }^{49}$

Due to the anguish entailed, the inspired seer could not enter the state of

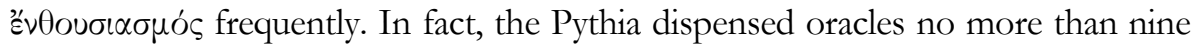
times a year. ${ }^{50}$ In the fourth century, the casting of lots at Delphi apparently became a common method of oracle-giving, ${ }^{51}$ possibly because of the dearth of

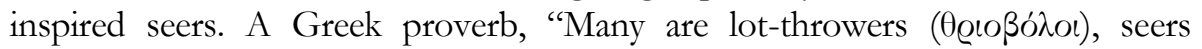
( $\mu \dot{\alpha} \nu \tau \varepsilon ı \varsigma)$ are few,"52 implies a contrast between the accessibility of cleromancy and the exclusivity of inspired prophecy.

Obtaining a response from a prophetic sanctuary was a troublesome and costly enterprise. ${ }^{53}$ It was obviously much easier to look into a collection of oracles or inspect the entrails of sacrificial animals. Yet there was a clear tendency to seek divinely induced predictions at Delphi, Didyma and other centers of ecstatic prophecy, whenever important issues had to be resolved. Even the proPersian position of Delphi during the Persian war did not discourage Athenians from consulting the Pythia. ${ }^{54}$ This preference for a kind of prophecy which was much more costly in material resources and human effort can be explained only if the obtained predictions were valued more highly. Messages coming directly from the gods were indeed treasured, since "the less the human being participates in prophecy, the more divine it is," to quote A. Piñero. ${ }^{55}$

Given the low availability of direct prophecy, it is easy to understand the demand for indirect divination, especially by armies on the move, in situations when an immediate response was required: no army could wait for a seer to attain ecstasy and start to prophesy. The diviners accompanying military contingents often belonged to families of $\mu \alpha \dot{v} \tau \varepsilon \iota \varsigma$ and formed guilds, tracing their origins to mythical ancestors prominent in the same craft, like other intellectuals, such as

47 VI, 45-50: et rabie fera corda tument.

48 Aesch., Agamem., 1035-1330; Mazzoldi (2001), p. 94-97.

49 Athen., 614b; BONNECHERE (2003), p. 249-271.

${ }^{50}$ Roux (1976), p. 70-75; PARKE (1939), p. 15; AMANDRY (1950), p. 81.

51 Amandry (1950), p. 25-36; PARKe - Wormell (1956), vol. 1, p. 18; WhitTaker (1965), p. 27; GROTTANELLI (2005), p. 130.

52 Steph. Byz., s.v. Thria.

53 AMANDRY (1950), p. 86-103.

54 BOWDEN (2005).

55 PiÑERO (1991), p. 17. 
physicians. ${ }^{56}$ The engagement of many military seers in the regular aristocratic lifestyle ${ }^{57}$ highlighted the profound difference between diviners and ecstatic prophets; the latter were often of humble origin and female, and their lifestyle could be secluded and peculiar in many respects. ${ }^{58}$ In a word, diviners were professionals blessed with inborn talents and acquired skills, while the main distinction of ecstatics was to be chosen as mouthpieces of the gods. ${ }^{59}$

\section{Arguments in support of the traditional approach: compar- ative evidence}

\subsection{Prophecy as mediation}

In Ancient Near Eastern studies, the communicative aspect of prophecygiving is emphasized: prophecy is defined as "human transmission of allegedly divine messages,"60 in sharp contrast to divination, based on observation of facts or events and their interpretation. The focus is on intermediation between the divine and the human, which results in a revelation delivered by the prophet to his audience. M. Nissinen insists that "the prophetic process of transmission consists of the divine sender of the message, the message itself, the human transmitter of the message and the recipient(s) of the message. These four components should be transparent in any written source to be identified as a specimen of prophecy." 61

Sources of different provenance distinguish between modes of prophecy. In ancient Israel, there were three customary ways to learn Yahweh's will, clearly perceived as dissimilar: "And when Saul inquired of the Lord, the Lord did not answer him, either by dreams, or by Urim, or by prophets". ${ }^{62}$ The Urim and Thummim were a priestly form of divination, never described in detail. These objects were used as lots, giving binary responses. ${ }^{63}$ Dreams were considered an important channel used by the god to announce his will to people in all walks of life: perhaps that is the reason why dreams were deemed inferior to

56 Dillery (2005), p. 175, 200-207; JOHNSTON (2008), p. 110.

57 Trampedach (2008), p. 229; Johnston (2008), p. 117. However, some diviners were itinerant figures of doubtful status: DiLLERY (2005), p. 223.

58 Code of behavior of prophetic priests: the Pythia: Diod., XVI, 26, 6; Plut., Mor., 405c, 438c; PARKe (1939), p. 32; PARKE - WORMELl (1956), vol. 1, p. 34-40; Roux (1976), p. 64-69; the prophet at Claros: Iambl., De myst. III, 11; RoBerT (1967), p. 10; Ustinova (2009), p. 111, 124.

${ }^{59}$ Dillery (2005), p.172.

${ }^{60}$ Nissinen (2003), p. 1; Gurney (1981), p. 142; Overholt (1989), p. 17-25; Petersen (2000), p. 37; in Classical studies prophecy as mediation is examined by RosEnberGER (2001), p. $127-176$.

\footnotetext{
${ }^{61}$ NisSinen (2003), p. 2.

${ }^{62}$ I Sam., 28, 6, cf. Deut., 13, 1-2.

${ }^{63}$ GrabBe (1995); PorTer (1981), p. 206.
} 
pronouncements by prophets. ${ }^{64}$ In the Old Testament tradition, discussed below, the prophetic voice is beyond any doubt superior to other modes of prophecy.

The same tripartite division of manifestations of the divine will is attested in a Hittite text known as Plague Prayers of Mursilis. The king asks the gods to reveal the reason for their anger: "Either let it be established by an omen, or let me see it in a dream, or let a prophet declare it!" 65 An inscription of Assurbanipal refers to "good omens, dreams, speech omens, and prophetic messages." 66 In these texts, the hierarchy of divination modes is only hinted at by their order in the lists, yet the differentiation between the modes is quite apparent. Thus, modes of prophecy are far from being a modern construal: they were perceived as such in the second millennium BC.

\subsection{Modes of divination in the ancient Mediterranean and the Middle East}

Inspired prophecy was comparatively rare in the ancient Mediterranean. In the ancient Near East, the usual method of learning the gods' will was by deciphering the language of signs, most commonly extispicy. ${ }^{67}$ In pharaonic Egypt, direct prophecy did not exist: deities announced their will by movements, to be interpreted and recorded by the priests. ${ }^{68}$ In Italy, imported oracles, mostly of Greek origin, were based on divine inspiration, while the normal indigenous mode of divination was by lots. ${ }^{69}$ As for the Etruscans, prophetic figures were prominent in their mythical past, but absent from reallife divinatory practices. ${ }^{70}$ Thus, although direct communication with the gods through mediums, or through visions and dream-visions, is known in the Near East, in Mesopotamia (Old Babylonian and Neo-Assyrian texts to be discussed p. 202.

64 E.g. Gen., 28, 11-20; 46, 1; Deut., 13; Jer., 27, 9; Malamat (1989), p. 92; PorTer (1981),

65 No. 2, ANET, no. 395, about third quarter of the $14^{\text {th }}$ cent. BC.

66 NiSSINEN (2003), no. 101 v. 93.

67 GuRNeY (1981); BOTTÉro (1974); STÖKL (2012a). Regrettably, I did not have an opportunity to consult the most recent book by J. STÖKL (2012b).

68 ASSMANN (2001), p. 154; RAY (1981); GRABBE (1995), p. 86; Wilson (1980), p. 124-128.

${ }^{69}$ Champeaux (1990), p. 271; GuitTARd (2007), p. 223-224.

70 Briquel (1990), p. 74; cf. PAirault-MASSA (1985). J.-R. JANNOT (2005, p. 33) convincingly argues that the few cases of consulting oracles by Etruscans are associated with Greek practices, very different from disciplina etrusca (see also PAIRAULT-MASSA [1985], p. 66; GUITTARD [2007], p. 289-341). 
below), in the Syro-Phoenician area, ${ }^{71}$ as well as in Anatolia (Hittites ${ }^{72}$ ), it seems to have played a minor role in these civilizations. ${ }^{73}$

There are some exceptions. In Mesopotamia, inspired prophecy is attested by approximately sixty tablets, dated ca. $1800-1750$ BC, discovered at Mari, ${ }^{74}$ in addition to several dozen texts from Assyria, dated a millennium later. ${ }^{75}$

At Mari, prophetic pronouncements, some spontaneous and others responses to queries, were made by cult officials and lay people. Among the diviners are both women and men. Some prophetic figures are dubbed āpilums, 'respondents,' while others are mubhûms, 'ecstatics. ${ }^{76}$ Divinely inspired mediums at Mari may be divided into three categories: cult officials in temples (for instance, transvestite or eunuch functionaries called assinnum), ${ }^{77}$ persons specially associated with a particular god who received a divine message, and laypersons visited by a deity in temples or elsewhere. Several gods used ecstatic mediums as their mouthpieces. ${ }^{78}$ Ecstatic prophets, even those participating in elaborate ceremonies in temples, sometimes failed to perform: ritual prescriptions of Ishtar's temple provide for every eventuality, including the possibility that a mubhum "is not able to prophesy." 79 Side by side with direct prophecy, traditional methods of divination by signs continued to flourish, and played the main role in prediction of the future.

We do not know much of the background and personal qualities of Mari prophets, but the few extant details indicate that their behavior was considered bizarre. At least one category of mediums are described as 'madmen' or 'ecstatics.' Their trances presumably did not affect their ability to speak understandably - or to be interpreted by scribes. In one case, a mubhüm of Dagan devoured a lamb raw, and later described his act as a sign of pestilence. ${ }^{80}$ Androgynous assinnum differed from the general population by definition, but Mari texts provide no detailed references to their function and behavior. All the mediums, both cultic personnel and laypersons, seem to have played peripheral

\footnotetext{
${ }^{71}$ SEOW (2003), nos. 136-138; WILSON (1980), p. 129-133.

72 ANET, no. 395.

73 GURNEY (1981), p. 146; PIÑERO (1991), p. 15.

74 About 50 of ca. 20000 texts, Durand (1997); ANET, nos. 623-626; NiSSINEN (2003),

75 Of ca. 30000 texts unearthed, NissinEN (2003), nos. 68-118; (2000), p. 89, cf. PARPOLA (1997); GURNEY (1981).

76 äpilum: Nissinen (2003), nos. 1-5, 8; mubbûm: ibid., nos. 10, 12, 16, 25, 31, 32; Malamat (1989), p. 85.

77 NisSinen (2003), nos. 7, 8, 22, 23.

${ }^{78}$ Ibid., p. 16.

${ }^{79}$ Ibid., nos. 51, 52.

${ }^{80}$ Nissinen (2003), no. 16; GrabBe (2000), p. 22; HufFmon (2000), p. 49.
} p. 13-77. 
roles in the society and cult, but in some cases received remuneration from higher social groups. ${ }^{81}$

Neo-Assyrian words for 'prophet' were mahhû, meaning 'mad' or 'frenzied,' and raggimu, deriving from 'to cry, proclaim.' Several texts explicitly indicate that persons described as mabhû or raggimu transmitted divine words while in a state of frenzy. Ecstatic prophets could be male, female or transgender, and many were affiliated with the worship of Ishtar. ${ }^{82}$ As in Mari, in Assyria the behavior of ecstatics was unpredictable: a raggimu could "lack a vision" and be unfit to perform. ${ }^{83}$

Ecstatic prophecy, a precious commodity dependent on the will of the gods, was open-ended and hard to manipulate. In contrast, inductive divination was performed by scholars, representing a long tradition of expert erudition. M. Nissinen highlights the difference between rational interpretation of signs by male intellectuals, and ecstatic prophets, mainly women, acting as direct mouthpieces of gods and never writing themselves: "in Assyria, the roles of scholar and prophet are not interchangeable. The inductive and non-inductive methods of divination never mixed." 84 It is evident why soothsaying by indirect methods was preferred: it was more available, relatively easy to control and did not require the extraordinary states of consciousness indispensable for ecstatic prophecy. Small wonder that most experts consider direct divination at Mari and in Assyria to have been peripheral to the traditional divination by signs: it is the situation in Greece, where the reverse was true, that calls for explanation.

In Israel in the monarchical period (ca 1000-586 BCE), 85 ecstatic prophecy played an outstanding role. ${ }^{86}$ Quite remarkably, it was usually not reliant on the temple in Jerusalem. ${ }^{87}$ Thus, of the three modes of inspired prophecy known at Mari and in Greece, only that based on independent seers was practiced in Israel.

The Old Testament prophet $(n \bar{a} b \hat{\imath})$ or seer $(h \bar{o} z \hat{\imath}$, rón $\hat{e}$ is an intermediary between the human and the divine worlds. This intermediary is sometimes called 'man of god,' and the experience is commonly referred to as hazon, 'vision' ${ }^{88}$ A revelation could comprise mental pictures of the future, or sights

81 Malamat (1989), p. 90-94.

82 Parpola (1997), p. IL-L; NisSinen (2000), p. 91-93.

${ }^{83}$ HufFmon (2000), p. 61.

${ }^{84}$ NisSinEN (2000), p. 109.

${ }^{85}$ For the ongoing debate on the accuracy of the data on early prophecy see CAROLL (1989); BARSTAD (1993).

86 Parker (1993).

87 Lindblom (1962), p. 80-82, 208; Petersen (2000), p. 35; Grabbe (1995), p. 112-113; Caroll (1989), p. 211-212; Overholt (1989), p. 75.

88 Huffmon (2000), p. 63-69; Grabbe (1995), p. 82-84, 108-112; Wilson (1980), p. 136-140, 256-257; LindBLOM (1962), p. 112-137. Female prophets are exceptional, but seem to perform in the same manner as male seers (II Reg., 22, 11-20; II Chr., 34, 22-28; Jud., 4-5). It is noteworthy that god-inspired vision is attested also by an inscription discovered at Deir Alla in Jordan (840- 
of the other world, such as encounters with divine councils, heavenly armies and awesome god-sent apparitions. Historically, most experts contrast Moses to early prophets, such as Samuel, Elijah and Elisha, to classical prophets, such as Jeremiah and Ezekiel. The difference between Hebrew and pagan prophets, and between true and false prophets, are also important. ${ }^{89}$

Visions are often ascribed to the 'hand of Yahweh' or 'spirit of Yahweh' coming upon the prophet, which clearly indicates possession by Yahweh. Yahweh charges the prophet with a message: the wish of the prophet to speak or of the audience to listen is irrelevant. ${ }^{90}$ Only to Moses did the god speak clearly, face to face, whereas other prophets received vague messages by means of visions or dreams. ${ }^{91}$ The message could be a reply to an inquiry - common people and kings came to prophets to seek the word of Yahweh, - or an unsolicited oracle delivered by the divine inspiration. ${ }^{92}$

The revelatory trance of 'men of god' could be spontaneous and uncontrolled or deliberately induced by various methods, such as rhythmic music, dancing and even use of hallucinogens. ${ }^{93}$ In many cases, the seer's trance is referred to clearly. For instance, Balaam is described as "falling down" while prophesying: he "who hears the words of God, and knows the knowledge of the Most High, who sees the vision of the Almighty, falling down, but having his eyes uncovered." 94

The oracles were normally given in the form of oral poetry, to be written down later and edited in later centuries, but these texts doubtlessly reflect historical reality. ${ }^{95}$ Receiving the divine message and uttering prophecy could be both a joy and a torture. ${ }^{96}$ Such figures as Samuel, Elijah, and Elisha combined the characteristics of sages, sorcerers, medicine men and seers: they multiplied oil, flour and other substances, called down fire or water from the heavens, purified lands, healed leprosy, and performed the supreme feat of resurrecting the dead. ${ }^{97}$ We are fortunate to have detailed accounts of the unearthly visions

760 BCE), which states that the pagan prophet Balaam, known from the Biblical tradition, was a "seer of the gods," Num., 22-24; VAN KOOTEN - VAN RUTTEN (2008).

${ }^{89}$ GrabBe (1995), p. 113.

${ }^{90}$ Eq., 3, 10; Jes., 6, 9; Jer., 20, 8; LindBLOM (1962), p. 109-110, 148-165.

91 Num., 12, 6-8.

92 Enquiries: I Reg., 14, 3; 22, 5; II Reg., 1, 3; 8, 7, Jer., 21, 2; Jes., 30, 2; unsolicited oracles: I Reg., 11-13; I Sam., 2, 27; Jes., 21, 10; Jer., 37, 20; Lindoblom (1962), p. 71-72, 110-111.

93 E.g. 1 Sam., 10, 5-6, 10; 1 Reg., 20, 36-38; 2 Reg., 3, 15; Zach., 13, 6; 4 Esra, 14, 39-41; LINDBLOM (1962), p. 93; WILSON (1980), p. 147-150.

94 Num., 24, 15-16, 93; LiNDBLOM (1962); WiLSON (1980), p. 147-150.

95 Barstad (1993), p. 59; cf. JoYCE (2007), p. 16.

${ }^{9}$ Jer., 15, 6; 4, 19; 20, 7-9.

97 I Reg., 17-38; II Reg., 1-2; Aune (1983), p. 83, 86-87; GrabBE (1995), p. 149; LindBlom (1962), p. 47-104, 197-202; OverholT (1989), p. 89-111. For 'acts of power' as socially sanctioned proofs of the prophetic authority see OVERHOLT (1986), p. 339. 
of some Hebrew prophets, ${ }^{98}$ which provide a glimpse of the range of complex multi-stage hallucinations experienced by ancient seers. ${ }^{99}$ The behavior of many seers was so manifestly abnormal that hostile sources branded them as mad. ${ }^{100}$ This conduct often followed stereotypical behavior patterns, reflecting social expectations from an inspired prophet, who was both venerated and feared. ${ }^{101}$

The stereotypical and identifiably abnormal behavior of many Hebrew prophets calls to mind the peculiarities of Greek $\mu \alpha \dot{\nu} \tau \varepsilon \iota \varsigma$ and allows a better understanding of the popular classification of divinely inspired seers as a special category: in both ancient Israel and Greece being a prophet meant being deviant. In both traditions, prophecy-giving is often presented as agonizing. The idea of annulment of the mental abilities of the prophet, who becomes a mere instrument used by the deity to communicate his message, is central and clearly pronounced in the Hebrew tradition, and was later adopted by the Christian apologetic. ${ }^{102}$

In sum: although Greek culture was not exceptional in its recognition of cult officials, free-lance seers and laypeople as legitimate mediums, it was distinctive in two respects. Firstly, its emphasis on direct communication with the gods as the ultimate mode of divination is comparable only to the Old Testament attitude to prophecy. Secondly, during the late Archaic and Classical ages, direct prophecy in Greece was distinguished by two traits - superior status and association with sanctuaries - a combination unparalleled in the ancient Near Eastern world. This is one of the unique characteristics of Greek culture, and its comprehension is possible only if the ancient distinction between direct and indirect prophecy is maintained and used as a heuristic tool.

\section{Conclusions}

It is quite obvious that inspired prophecy and prediction by signs were two modes of divination, and both were intended to lighten the unbearable uncertainty of being. ${ }^{103}$ It is also evident that both were considered divine: they were aids granted to the mortals by the immortals. ${ }^{104}$ Within this basic framework, ${ }^{105}$ direct and indirect divination are as different as poetry and scholarly research: the latter results from meticulous labor, while the former is

\footnotetext{
${ }^{98}$ For instance, Eq., 1-3; Jes., 6; cf. Clements (1996), p. 145-169; JoyCE (2007).

${ }^{99}$ UstinOva (2011), p. 54-55.

100 Jer., 29, 26; Hos., 9, 7; II Reg., 9., 1; I Sam., 19, 2-24; Jes., 20, 3; Ez., 4-5.

101 WiLSON (1979); (1980), p. 87, 153, 177; LINDBLOM (1962), p. 74, 102.

102 Piñero (1991), p. 17, 29, cf. Nasrallah (2003).

103 JOUAN (1990).

104 Plato, Tim., 71d-e; Symp., 188b-d; Xen., Mem. I, 4, 14-15.

105 'Prophecy and omen divination belong to the same symbolic universe,' NISSINEN (2010), p. 345; cf. JOHNSTON (2008), p. 9.
} 
created by inspiration, not fully understood even today. ${ }^{106}$ A singular individual, like Vladimir Nabokov or the prototype of Melampous, may be gifted in both spheres, but these rare exceptions only highlight the rule. Examples of coexistence of direct and indirect divination in the same oracular center and the cooperation of ecstatic and non-ecstatic temple personnel merely demonstrate that inspired prophecy was interwoven with other cultic phenomena. Methodologically, it is very important to consider inspired prophecy and divination by signs separately, since they involve quite distinct activities and require different abilities on the part of the practitioners.

From the point of view of the diviner, indirect divination requires technical knowledge, intuition and astuteness, qualities that are inborn or acquired by the seer and may be retained throughout his life. In contrast, direct prophecy requires not only a general predisposition, but also the ability to induce vatic trance spontaneously or on request, and endure its strain - an ability not entirely controllable even by experienced ecstatics. Lifestyles of ecstatic prophets were usually abnormal, contrary to that of diviners by signs, who adhered to social norms. ${ }^{107}$

From the point of view of the public, technical divination was accessible: extispicy could be performed anywhere and other methods were also almost always at hand. Indirect divination could be controlled, even though with some effort. ${ }^{108}$ In contrast, the mere fact of ecstatic prophecy-giving was not guaranteed, and obtaining the right to seek a god's advice in an oracular center was a time,- energy- and resource-consuming enterprise. Finally and most significantly, the result of the endeavor was open-ended.

Prophecy is a social phenomenon, and hence attempts to comprehend it are bound to be based on interpretation of its social context, which includes the involvement of communities in acts of prophecy-giving. ${ }^{109}$ In Greece, public demand for inspired prophecy was great, and brought about the burgeoning of oracular centers based on prophecy by temple officials or even on direct communication between the inquirer and the deity. While most ancient Mediterranean cultures tolerated ecstatic prophecy as a marginal phenomenon only, in Greece its institutionalization in oracular sanctuaries was the utmost the polis society could do to regulate the mysterious sphere of the prophetic mania. Discussions of such a complex phenomenon as divination from many other perspectives may be stimulating and rewarding. While the ancient dichotomy between direct and indirect prophecy is far from absolute, to discard this

\footnotetext{
106 Poets compared to seers in Greece: CHADwICK (1942), p. 2-3; MORRISON (1981), p. 93; VERNANT (1983), p. 76; DiLlery (2005), p. 185; BOWRA (1964), p. 6-8.

107 Nissinen (2010), p. 343-345; DiLLERY (2005).

108 DiLLON (1996), p. 119.

109 Overholt (1989), p. 17-25; 86-115.
} 
distinction altogether would be to strip Greek culture of one of its unique characteristics.

Yulia UsTINOVA

Ben-Gurion University of the Negev

BEER SHEVA 84105

Israel

E-mail:yulia@bgu.ac.il

\section{Bibliography}

A. Annus (ed.), Divination and Interpretation of Signs in the Ancient World, Chicago, 2010.

W.G. ARNoTT, “Nechung. A modern parallel to the Delphic oracle?,” G\&R 36 (1989), p. 152-157.

J. Assmann, The Search for God in Ancient Egypt, Ithaca-London, 2001.

H.M. BASTAD, "No prophets? Recent developments in Biblical prophetic research and ancient Near Eastern prophecy," Journal for the Study of Old Testament 57 (1993), p. 39-60.

-, "Comparare necesse est? Ancient Israelite and ancient Near Eastern prophecy in a comparative perspective," in NISSINEN (2000), p. 3-11.

N. BELAYCHE, J. RÜPKE, "Divination romaine," ThesCRA III (2005), p. 79-104.

J. BOTTÉRO, "Symptômes, signes, écritures," in J.-P. VERnANT (ed.), Divination et rationalité, Paris, 1974, p. 70-197.

P. BONNECHERE, Trophonios de Lébadée, Leiden, 2003.

A. Bouché-LeClerCQ, Histoire de la divination dans l'Antiquité, Paris, 1879-1882.

H. Bowden, Classical Athens and the Delphic Oracle, Cambridge, 2005.

C.M. Bowra, Pindar, Oxford, 1964.

J.N. Bremmer, "Prophets, seers, and politics in Greece, Israel, and Early Modern Europe," Numen 40 (1993), p. 150-183.

D. BRIQUEL, "Le paradoxe étrusque : une parole inspirée sans oracles prophétiques," Kernos 3 (1990), p. 67-75.

W. BURKERT, "Itinerant diviners and magicians: a neglected element in cultural contacts," in R. HäGG (ed.), The Greek Renaissance of the Eighth Century BC. Tradition and Innovation, Stockholm, 1983, p. 115-119.

—, "Mantik in Griechenland," ThesCRA III (2005a), p. 1-51.

-, "Signs, commands, and knowledge: Ancient divination between enigma and epiphany," in JOHNSTON - STRUCK (2005), p. 29-49 [= BURKERT (2005b)].

R.N. Caroll, "Prophecy and Society," in R.E. Clements (ed.), The World of Ancient Israel, Cambridge, 1989, p. 203-225.

M. Casevitz, "Mantis : le vrai sens," REG (105) 1992, p. 1-18.

N.K. Chadwick, Poetry and Prophecy, Cambridge, 1942.

J. Champeaux, "Sors oraculi: les oracles en Italie sous la république et l'empire," MEFRA 102 (1990), p. 271-302.

P. Chantraine, Dictionnaire étymologique de la langue grecque, Paris, 1983-84.

R.E. Clements, Old Testament Prophecy. From Oracles to Cannon, Louisville, 1996.

H.R.E. Davidson, "The Germanic world," in LOEWE - BLACKer (1981), p. 115-141.

B.C. DiETRICH, “Oracles and divine inspiration,” Kernos 3 (1990), p. 157-174. 
J. Dillery, "Chresmologues and manteis: Independent diviners and the problem of authority," in JOHNSTON - STRUCK (2005), p. 167-231.

M. DiLlon, “The importance of oionomanteia in Greek divination,” in M. DiLlon (ed.), Religion in the Ancient World, Amsterdam, 1996, p. 99-121.

E.R. DoDDs, The Greeks and the Irrational, Berkeley et al., 1973.

J.-M. Durand, "Les prophéties des textes de Mari," in J.-G. HeinTZ (ed.), Oracles et prophéties dans l'antiquité, Paris, 1997, p. 115-134.

R. FLACELIÈRE, Devins et oracles grecs, Paris, 1972.

M.A. Flower, The Seer in Ancient Greece, Berkeley/Los Angeles, 2008.

H. FrISK, Griechisches etymologisches Wörterbuch, Heidelberg, 1973-79.

A. Gartziou-Tatti, "L'oracle de Dodone. Mythe et ritual”, Kernos 3 (1990), p. 175-184.

S. GEORGOUd, "Les porte-parole des dieux : réflexions sur le personnel des oracles grecs", in I. Chirassi Colombo, T. SePpildi (eds.), Sibille e languaggi oracolari, Pisa/Rome, 1998, p. 315365.

—, "Des sons, des signes et des paroles : la divination à l'œuvre dans l'oracle de Dodone," in GEORGOUdi - KOCH PIETTRE - SCHMIDT (2012), p. 55-90.

S. Georgoudi, R. Koch Piettre, F. Schmidt (eds.), Présages, rites, destin dans les sociétés de la Méditerranée ancienne, Leiden, 2012.

L.L. Grabbe, Priests, Prophets, Diviners, Sages. A Socio-Historical Study of Religious Specialists in Ancient Israel, Valley Forge, PA., 1995.

—, "Ancient Near Eastern prophecy from an anthropological perspective," in NISSINEN (2000), p. 13-32.

C. Grottaneldi, "Sorte unica pro casibus pluribus enotata. Literary texts and lot inscriptions as sources for ancient cleromancy," in JOHNSTON - STRUCK (2005), p. 129-146.

C. GuitTARD, Carmen et prophéties à Rome, Turnhout, 2007.

O.R. Gurney, “The Babylonians and Hittites,” in Loewe - BlaCker (1981), p. 142-173.

R. HACKFORTH, Plato's Phaedrus. Translated with an Introduction and Commentary, Cambridge, 1972.

H.B. Huffmon, “A company of prophets: Mari, Assyria, Israel,” in Nissinen (2000), p. 47-70.

D. Jaillard, "Plutarque et la divination : la piété d'un prêtre philosophe," RHR 224 (2007), p. $149-169$.

J.-R. Jannot, Religion in Ancient Etruria, Madison, Wisconsin, 2005.

S.I. Johnston, Ancient Greek Divination, Oxford, 2008.

S.I. Johnston, P.T. STruck (eds.), Mantikê. Studies in Ancient Divination, Leiden, 2005.

F. JouAn, “L’oracle, thérapeutique de l'angoisse,” Kernos 3 (1990), p. 11-28.

P.M. JoYCE, Ezekiel: A Commentary, New York/London, 2007.

A. KARP, "Prophecy and divination in Archaic Greek Literature," in R.M. BERChMAn (ed.), Mediators of the Divine. Horizons of Prophecy, Divination, Dreams and Theurgy in Mediterranean Antiquity, Atlanta, 1998, p. 9-44.

G.H. Van Kooten, J. Van Ruiten (eds.), The Prestige of the Pagan Prophet Balaam in Judaism, Early Christianity and Islam, Leiden, 2008.

J. LARSON, Greek Nymphs, Oxford, 2001.

J. Lindblom, Prophecy in Ancient Israel, Oxford, 1962.

M. LOEWE, C. Blacker (eds.), Divination and Oracles, London, 1981.

A. Malamat, Mari and the Early Israelite Experience, Oxford, 1989.

G. MANETTI, Theories of the Sign in Classical Antiquity, Bloomington/Indianapolis, 1993.

L. Maurizio, "Anthropology and spirit possession: A reconstruction of the Pythia's role at Delphi," JHS 115 (1995), p. 69-86. 
S. Mazzoldi, Cassandra, la vergine e l'indovine, Pisa/Rome, 2001.

J.D. Mikalson, Greek Popular Religion in Greek Pbilosophy, Oxford, 2010.

J.S. Morrison, "The Classical World," in Loewe - Blacker (1981), p. 87-114.

G. NAGY, "Greek poetry, prophecy, and concepts of theory," in J.L. KugEL (ed.), Poetry and Prophecy. The Beginnings of a Literary Tradition, Ithaca/London, 1990, p. 56-64.

L. Nasrallah, An Ecstasy of Folly. Prophecy and Authority in Early Christianity, Cambridge, Mass., 2003.

M.P. NiLsson, Geschichte der griechischen Religion, Munich, 1961-1967.

M. Nissinen (ed.), Prophecy in Its Ancient Near Eastern Context, Atlanta, 2000, p. 89-114.

—, "The socioreligious role of the Neo-Assyrian prophets," in Nissinen (2000), p. 89-114.

-, Prophets and Prophecy in the Ancient Near East, Atlanta, 2003.

—, "Prophecy and omen divination: Two sides of the same coin," in Annus (2010), p. 341-351.

T.W. Overholt, Prophecy in Cross-Cultural Perspective, Atlanta, 1986.

—, Channels of Prophecy, Minneapolis, 1989.

F.-H. Pairault-Massa, "La divination en Étrurie. Le Ive siècle, période critique," Caesarodunum Suppl. 52 (1985), p. 56-115.

H.W. PARKe, A History of the Delphic Oracle, Oxford, 1939.

H.W. Parke, D.E.W. Wormell, The Delphic Oracle, Oxford, 1956.

R. Parker, "Greek states and Greek oracles," in A. Cartledge, F.D. Harvey (eds.), Crux. Essays Presented to G. E. M. de Ste. Croix on his 75th Birthday, Sidmouth, 1985, p. 298-326 [republished in R. BuxTON, Oxford Readings in Greek Religion, London, 2000, p. 76-108].

S.B. PARKER, "Official attitudes toward prophecy at Mari and in Israel," VT 43 (1993), p. 50-68.

S. Parpola, Assyrian Prophecies, Helsinki, 1997.

D.L. Petersen, "Defining prophecy and prophetic literature," in Nissinen (2000), p. 33-44.

A. PIÑERO, "A Mediterranean view of prophetic inspiration: On the concept of inspiration in the Liber Antiquitatum Biblicarum by Pseudo-Philo," MHR 6 (1991), p. 5-34.

J.R. Porter, “Ancient Israel," in Loewe - Blacker (1981), p. 191-214.

A. Powell, "Divination, royalty and insecurity in Classical Sparta," Kernos 22 (2009), p. 35-82.

J.F. RAY, “Ancient Egypt,” in LOEWE - BlaCKer (1981), p. 174-190.

L. Robert, "L'oracle de Claros," in C. Delvoye, G. Roux (eds.), La civilisation grecque, Brussels, 1967, p. 305-312.

V. Rosenberger, Griechische Orakel. Eine Kulturgeschichte, Darmstadt, 2001.

G. Roux, Delphes. Son oracle et ses dieux, Paris, 1976.

C.J. Rowe, Plato: Phaedrus, Edited with Translation and Commentary, Warminster, 1986.

S. SCHRÖDER, Plutarchs Schrift De Pythiae oraculis. Text, Einleitung und Kommentar, Stuttgart, 1990.

C.-L. SEOW, "West Semitic Sources," in Nissinen (2003), p. 201-218.

G. SHAw, "Divination in the Neoplatonism of Iamblichus," in R.M. BERCHMAN (ed.), Mediators of the Divine. Horizons of Prophecy, Divination, Dreams and Theurgy in Mediterranean Antiquity, Atlanta, 1998, p. 225-267.

J. STÖKL, "Ancient Near Eastern prophecy," in M.J. BODA, J. GORDON MCCONVILLE (eds.), Dictionary of the Old Testament Prophets, Downers Grove Ill./Nottingham, 2012a, p. 16-24.

—, Prophecy in the Ancient Near East, Leiden, 2012b.

R. STONEman, The Ancient Oracles. Making the Gods Speak, New Haven, 2011.

K. Trampedach, "Authority disputed: The seer in Homeric epic," in B. Dignas, K. TrampedACH (eds.), Practitioners of the Divine. Greek Priests and Religious Officials From Homer to Heliodorus, Cambridge Mass./London, 2008, p. 207-230. 
Y. Ustinova, Caves and the Ancient Greek Mind. Descending Underground in the Search for Ultimate Truth, Oxford, 2009.

-, "Consciousness alteration practices in the West from prehistory to late antiquity," in E. Cardeña, M. Winkelman (eds.), Altering Consciousness. Multidisciplinary Perspectives. Vol. 1. History, Culture, and the Humanities, Santa Barbara, 2011, p. 45-71.

J.-P. VERnANT, Myth and Thought among the Greeks, London, 1983.

M.L. WEST, Indo-European Poetry and Myth, Oxford, 2007.

C.R. WhitTAKeR, "The Delphic oracle. Belief and behaviour in ancient Greece and Africa," HThR 58 (1965), p. 21-47.

R.R. WiLSON, "Prophecy and ecstasy: A reexamination," Journal of Biblical Literature 98 (1979), p. 321-337.

—, Prophecy and Society in Ancient Israel, Philadelphia, 1980.

A. WinitZER, "The divine presence and its interpretation in early Mesopotamian divination," in ANNUS (2010), p. 177-197.

E.M. ZEusse, “Divination,” Encyclopedia of Religion, IV (1987), p. 375-382. 